\title{
Experiences and Challenges of Foreign Agricultural Workers in Finland
}

T. E. A. Mattila, U. Ovaska, B. Kinnunen, V.-M. Tuure,

J. Leppälä, K. Taattola, V. Rinnola, R. H. Rautiainen

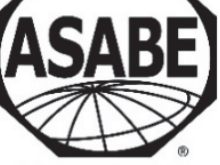

Research

\section{HighLIGHTS}

- Better control of musculoskeletal workload remains a key factor in improving working conditions on Finnish farms.

- Orientation and training of workers should be carefully prepared with attention to content, method, and timing.

- Continued training is needed, especially for foremen and the increasing number of longterm foreign workers.

ABSTRACT. Foreign workers have become an important part of the workforce on horticulture and livestock farms in Finland. The aim of this study was to investigate the experiences of foreign workers regarding their working and living conditions. We conducted semistructured theme interviews during two time periods: in 2008-2009 ( $n=40$ workers on eight farms) and again in 2018-2019 ( $n=9$ workers on four farms). We found variations in expectations and goals among workers when they take a job abroad. Compelling factors in the origin country included unemployment, low wages, and low standards of living, and enticing factors in the destination country included social relationships and expectations of better income. Personal networks had a strong role in the recruiting processes. Work on farms is physically demanding, and being a foreign worker affects social life in many ways, such as being separated from family and facing pressures from the home community to arrange jobs for others. New communication technologies have improved possibilities to stay in contact. Employers could contribute to better working and living conditions for foreign workers by improving work organization, ergonomics at work, orientation of new workers, and continued training of supervisors. Worker orientation and training should be carefully planned, taking into consideration the limited language skills, work competence requirements, and possibilities for career advancement of the workers. Commons Attribution-NonCommercial-NoDerivatives 4.0 International License https://creative commons.org/licenses/by-nc-nd/4.0/

Submitted for review on 16 January 2020 as manuscript number JASH 13893; approved for publication as a Research Article by the Ergonomics, Safety, \& Health Community of ASABE on 2 November 2020.

The authors are Tiina E.A. Mattila, Research Scientist, and Ulla Ovaska, Research Scientist, Natural Resources Institute Finland, Helsinki, Finland; Birgitta Kinnunen, Research Scientist, Finnish Institute of Occupational Health, Kuopio, Finland; Veli-Matti Tuure, Research Scientist, TTS Research Institute, Rajamäki, Finland; Jarkko Leppälä, Research Scientist, Natural Resources Institute Finland, Helsinki, Finland; Kirsti Taattola, Senior Advisor (retired), Finnish Institute of Occupational Health, Helsinki, Finland; Virve Rinnola, Project Specialist, Centre for Economic Development, Transport, and the Environment, Tampere, Finland; Risto H. Rautiainen, Professor, Department of Environmental, Agricultural, and Occupational Health, University of Nebraska, Omaha, Nebraska. Corresponding author: Tiina Mattila, FI-00790, Latokartanonkaari 9, 00790 Helsinki, Finland; phone: +358-025-536358; e-mail: tiina.mattila@luke.fi.

Journal of Agricultural Safety and Health

27(1): 13-28 C 2021 ASABE ISSN 1074-7583 https://doi.org/10.13031/jash.13893 
$\mathrm{F}$ oreign workers have become an important part of the agricultural labor force in Finland, especially in the horticultural sector. Various aspects of the living and working circumstances of foreign workers and associated migration policies and farm management challenges have been widely discussed in Europe in recent years (Ramos et al., 2020; Schuh et al., 2019; Dwyer et al., 2019; McNamara et al., 2018). In our study, foreign farm workers are defined as non-permanent migrants and permanent immigrants who are hired to work for wages on farms. The Natural Resources Institute Finland (Finnish abbreviation: Luke) estimated that there were 14,500 foreign farm workers in Finland in 2007. Nine years later, in 2016, the estimated number of foreign farm workers was 16,000 (Luke, 2019). In 2016, there were altogether 118,000 people working in agriculture or horticulture in Finland; $70 \%$ of them were Finnish farmers or their family members. Approximately $80 \%$ of farm work $(61,000$ full-time equivalent work years in total) was performed by farmers and their family members, and $6 \%$ was performed by foreign workers (Luke, 2019).

The modern history of foreign workers in Finnish agriculture and horticulture began in the early 2000s when many Estonians became interested in working in Finland. After the EU enlargement of 2004, the number of Estonian agricultural and horticultural workers diminished, and more seasonal migrant workers started to come from Russia and other nonEU countries, such as Ukraine and Thailand (Ovaska et al., 2011). The labor force flow to Finland still remains stronger from non-EU countries than from countries within the EU.

For a long time, foreign labor was mainly seen as an increase in the labor supply, which was believed to decrease wage levels over time. More recent studies have underlined the positive effects of immigrants on labor market outcomes and productivity at the local level. There are differences between the tasks that foreign and native workers are more likely to perform, and businesses can adjust their operations in response to immigration (Peri, 2016). Access to foreign labor brings certainty to businesses and enables risk-taking and increasing production. Foreign workers have an effect on the local economy because they are also consumers, supporting local businesses and the housing market. Moreover, they need to be considered in planning of public services, such as healthcare (Rye, 2018). In many rural areas with declining and aging populations, the local community is actively integrating immigrants. The involvement of the public sector, companies, and NGOs in the process has led to progress in local development (Mikkola and Morales, 2017).

While the contribution of foreign workers has been notable on European farms during the past 20 years, there have been only few studies on the health and safety of foreign farm workers. In Norway, Rye and Andrzejewska (2010) noted that even if minimum wages and working conditions are defined by rules and regulations, they are not followed in practice on farms. This is because of the disempowerment and weak negotiating position of foreign workers and because their baseline for wage level comes from their home countries, where wages are lower. In the U.K., Cross et al. (2008) found that the self-perceived health status of foreign farm workers was significantly lower than population norms. In southern Europe, Ahonen et al. (2009) found many faults in the working conditions of immigrant workers, such as lack of training and personal protective equipment, long working hours, and hard work with inadequate rest, which caused severe fatigue and difficulties in maintaining physical and mental health. Their study did not specifically focus on the agricultural sector, 
but some farm workers were included. In Greece, Alexe et al. (2003) found that migrants are a high-risk group for occupational injuries on farms, and their injuries tend to be more severe. Hoggart and Mendoza (2000) concluded that the working conditions for immigrants in the agricultural sector are not likely to improve because that sector often serves as an entry point to the labor market of the new country. The workers are satisfied with the working and living conditions because their employment is only short-term.

Safe and healthy working conditions are an important part of socially sustainable food production. Good working conditions and physical assets are also attractive factors when farm employers seek competent workers (Schuh et al., 2019). Ahonen et al. (2009) and Rye and Andrzejewska (2010) suggested that the working and living situations of foreign farm workers need to be addressed at the farm and individual levels. From this perspective, we explored the views of foreign farm workers in Finland regarding their work and life as employees in the agricultural and horticultural sector.

The objective of this study was to create a multi-faceted picture of the working life of foreign farm workers. The ultimate aim was to provide information for farm employers when considering new ideas for developing living and working conditions for their workers. The main research questions were: (1) How do foreign agricultural workers experience their working and living conditions in Finland? and (2) What are the challenges and opportunities for improving the working life of foreign farm workers?

\section{Material and Methods}

This descriptive study explored the experiences of foreign farm workers in interviews conducted during 2008-2009 and 2018-2019. While not aiming to compare the two periods, this approach provided a broader time perspective for gaining a picture of the experiences of foreign workers on Finnish farms. Our research method was a semi-structured theme interview. In the first part, the interview themes included background information, acquiring the job, motivation, orientation and training, working on the farm, work strain, mode of action in the case of injury or illnesses, supporting factors, communication and feedback, conflicts, leisure time, living on the farm and in the country, information needs, and general thoughts about the working experience. Each theme was addressed by asking a main question (e.g., "Why did you decide to come to Finland and to this farm in particular?", "Can you describe the orientation and training for work tasks when you started working on the farm?" and "Can you describe what you would do in case of illness?"). Further in-depth questions were asked when needed. In the second part, the focus was on work motivation and conditions, and the thematic questions covered work tasks, motivation, physical and social work context, straining factors, and development needs.

Most of the study farms were horticultural operations, while three were animal production farms (table 1). Of the horticultural farms, three were greenhouse operations (vegetables, herbs, flowers) and the rest practiced field production (strawberries, other berries, apples, potatoes, peas, and other vegetables). The animal farms had dairy cows, calves, and beef cattle. The study farms were in Finnish-speaking and Swedish-speaking regions.

Immediately before the interviews, the workers filled out a form with their demographic information. The interviewer then had an in-depth discussion with each worker. All interviews were transcribed for content analysis. The interview was conducted in Russian if that was the worker's native or well-understood language. Other interviews were conducted in English or Finnish. All interviews were conducted on farms because it was not possible to 
Table 1. Study participants.

\begin{tabular}{|c|c|c|c|c|}
\hline & & $\begin{array}{c}\text { Part 1 } \\
(2008-2009)\end{array}$ & $\begin{array}{c}\text { Part } 2 \\
(2018-2019)\end{array}$ & Total \\
\hline \multirow{2}{*}{ Gender } & Female & 22 & 4 & 26 \\
\hline & Male & 18 & 5 & 23 \\
\hline \multirow[t]{5}{*}{ Education } & University & 7 & 2 & 9 \\
\hline & Vocational or military & 15 & 7 & 22 \\
\hline & Senior high school & 2 & - & 2 \\
\hline & Elementary school & 3 & - & 3 \\
\hline & Student & 13 & - & 13 \\
\hline \multirow[t]{8}{*}{ Citizenship } & Ukrainian & 15 & 6 & 21 \\
\hline & Russian & 14 & - & 14 \\
\hline & Latvian & 4 & - & 4 \\
\hline & Bulgarian & 3 & - & 3 \\
\hline & Serbian & 2 & - & 2 \\
\hline & Estonian & 2 & 1 & 3 \\
\hline & Bosnian & - & 1 & 1 \\
\hline & Vietnamese & - & 1 & 1 \\
\hline \multirow[t]{2}{*}{ Production sector } & Horticulture & 36 & 9 & 45 \\
\hline & Animal production & 4 & - & 4 \\
\hline \multirow[t]{4}{*}{ Information about job } & Friends, relatives, acquaintances & 31 & 4 & 35 \\
\hline & Organization, university & 7 & 4 & 11 \\
\hline & Newspaper & 1 & - & 1 \\
\hline & Internet & 1 & 1 & 2 \\
\hline \multirow[t]{3}{*}{ Age (years) } & Average & 30 & 35 & 31 \\
\hline & Minimum & 18 & 26 & 18 \\
\hline & Maximum & 52 & 58 & 58 \\
\hline
\end{tabular}

take workers away from the farms during the workday. To minimize disturbances, we had flexibility in managing the times for interviews while aiming to have a large enough sample size for data saturation. There were three interviewers in the first part of the study and one interviewer in the second part. The workers did not receive payment for taking part in the study; however, refreshments or snacks were served when needed. Two researchers conducted the main analysis, and the findings were discussed with the research team.

In the first part of the study, data were collected in 2008 and 2009 on eight Finnish farms. Our aim was to get a diverse sample of workers including both horticultural and animal production farms, female and male workers, workers with long-term and temporary employment, and both newcomers and experienced migrant and immigrant workers. We continued data collection until all the defined criteria were fulfilled and the data started to saturate. The participating farms were found using networks and contacts among researchers and farm organizations. The data consisted of interview material from 40 foreign farm workers, including 22 females and 18 males (table 1); 13 participants were students, but only two were trainees (this being their official practical training period). Seven workers had graduated from a university, and 15 had some vocational (e.g., technician, bricklayer, baker) or military education. Most of the workers ( $83 \%$, or 33 workers) mentioned having earlier experience in farm work on the present farm, at other farms, or at home. However, the type of farm work experience was not explored further and could have been in very different circumstances (e.g., ranging from small farms with hand-milking to large collective farms with 200 to 400 cows). Most of the workers received information about the job from relatives, friends, or acquaintances. Seven had been hired with the help of a university or some other organization, one noticed an ad for the job in a newspaper, and one found information on the internet. The mean age of the workers was 30 years, the minimum age 
was 18 years, and the maximum age was 52 years. Some of the interviewed seasonal workers were working on the farm for the first time $(n=16)$, but some had been working there seasonally for more than ten years. Most of the workers lived on the farm. The most common citizenships were Ukrainian $(n=15)$ and Russian $(n=14)$, but there were also workers from Latvia, Bulgaria, Serbia, and Estonia who participated in our study.

In the second part of the study, data were collected in 2018 and 2019 on four Finnish farms (table 1). Our aim was to interview foreign workers on horticultural farms to update and complete the information obtained in the first part of the study. We used several communication channels, including farmer magazines, e-mails, and phone calls to contacts found on the internet (e.g., direct marketing farms), to find farms willing to participate. In addition to asking workers about their personal experiences, we interviewed foreign foremen on three farms about their views on foreign workers' life on Finnish farms.

The second part of the study contributed to the data with nine foreign farm workers (five female and four male). Two workers had graduated from a university, and seven had vocational education. Four of the workers received information about the job from relatives. Others found information on the internet either directly or via recruitment agencies. The mean age of the workers was 36 years, the minimum age was 26 years, and the maximum age was 58 years. All of the interviewed workers had been working on the same farm seasonally for several years. One of them had been working there for more than ten years. Two of the workers lived on the farm. The other seven had used the opportunity to stay permanently in Finland after several years of seasonal work. The most common citizenship was Ukrainian $(n=6)$, but workers from Bosnia, Estonia, and Vietnam also participated in the second part of the study.

In the analysis, all the data were read through several times, comments relating to each topic were collected together, and different themes were identified. The interpretation of themes aimed to identify factors that can be used when improving the working life of foreign workers (Beyer and Holzblatt, 1998; Braun and Clarke, 2006). The elements of the work ability model created by Ilmarinen (2006) were used as a framework for organizing the observed themes (tables 2 and 3). This work ability model introduces the main elements of working life: work (work conditions, work content and demands, work community and organization, supervisory work and management), human resources (values, attitudes, motivation, knowledge and skill, health, functional capacity), and social surroundings (family, close community, society) (Ilmarinen, 2006; Gould et al., 2008).

Further categorizing by motivational factors (e.g., a way of making a living for committed long-term workers, wandering workers who focus on earning money, trainees, traveling combined with earning money, workers from nearby areas for whom the job offered an easy opportunity to earn some extra money) was also tested but was abandoned due to complex overlaps.

This study was conducted by research staff at the Natural Resources Institute Finland (Luke), a governmental research institute for agriculture, forestry, and fishing (Finlex, 2014). This research complied with Luke's research ethics and information confidentiality rules and was not considered human subjects research.

\section{Results}

\section{Motivation}

The main motivational factor for taking a job abroad was money, but there were many 
Table 2. Straining and supporting factors of foreign farm workers in relation to work, health, family, and close community based on interview data.

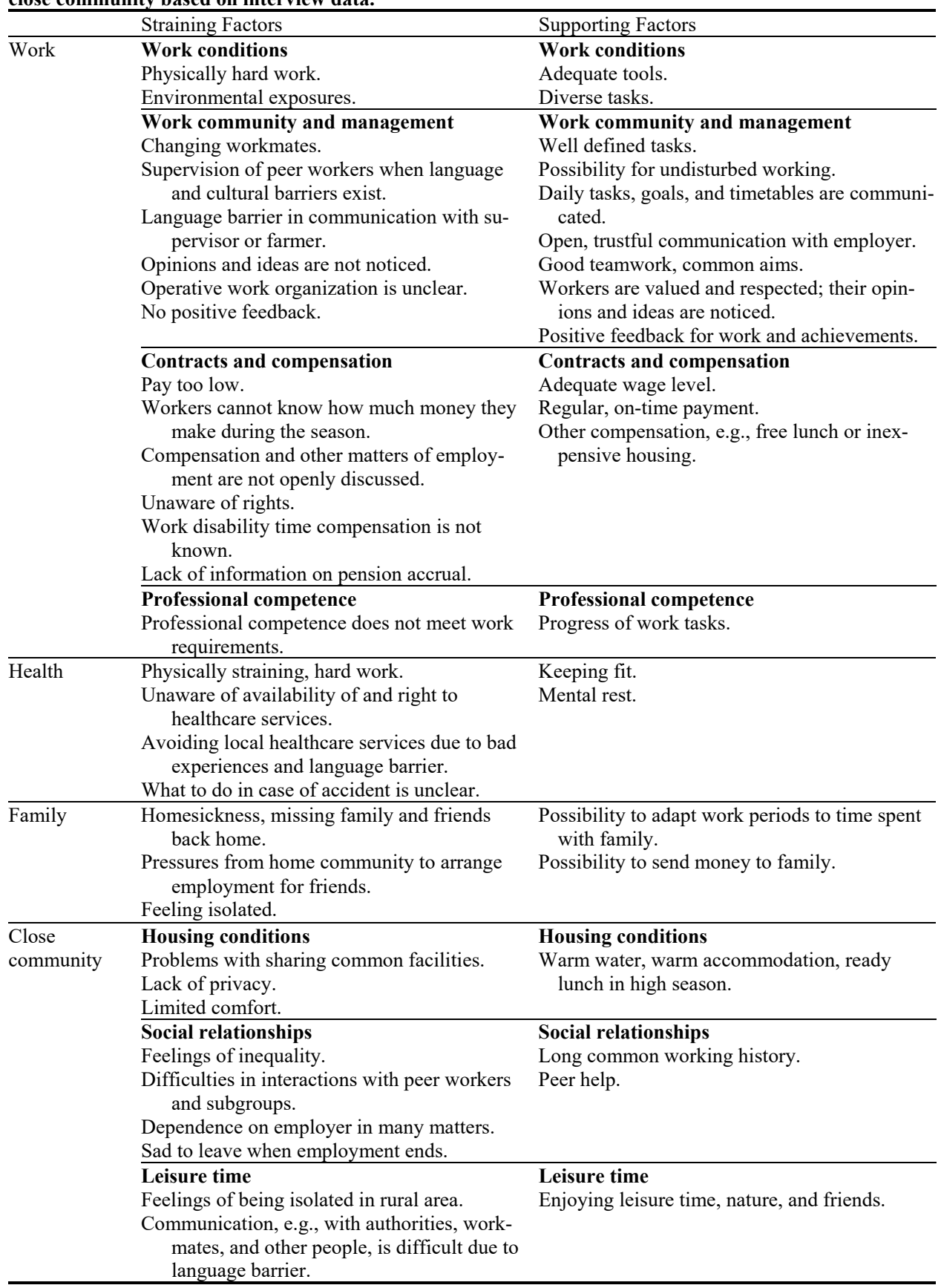


Table 3. Motivational factors of foreign farm workers based on interviews.

\begin{tabular}{ll}
\hline Pushing Factors in Country of Origin & Pulling Factors in Destination Country \\
\hline Unemployment & Positive information \\
Low living standards & Peer help \\
Low wages & Curiosity for new earning possibilities \\
& Traveling, new cultures and experiences \\
& Affection for the same farm, long work history \\
& Rewarding work community \\
& Trustworthy employer \\
& Good working comfort \\
& Good working conditions \\
& Welcome change to home circumstances, "mental refreshment", \\
\hline
\end{tabular}

personal variations in expectations and aims (table 3). Difficult circumstances, such as a low standard of living, low wages, or unemployment in the home country, encouraged people to find new opportunities somewhere else. For people from neighboring areas, such as Karelia, the short distance made it easy to come to Finland, and the wages were better than at home. Some workers mentioned working abroad and meeting new people as a welcome change in their everyday life or as a form of mental refreshment, even though working in the strawberry fields was physically hard. The experiences of friends and acquaintances made job opportunities attractive. Human relationships, a habit from long experience, work content, and normal working conditions were also mentioned. The term "normal working conditions" was described with attributes, such as work tasks are well-defined, workers are allowed to work in peace, the employer provides tools, listens to the workers' opinion, and pays wages on time. Feelings of this kind strengthened the workers' commitment to the workplace. Some of the workers come back repeatedly or have settled in Finland after receiving permission to stay permanently. In the first part of the study, most of these workers came from neighboring areas, such as Karelia, St. Petersburg, or Estonia. In the second part, they came mostly from Ukraine.

Comparing the more experienced foreign workers with younger newcomers, the differences were easy to notice. The newcomers had not created new networks on the farm or in the rural community, but they were willing to see the world, meet new people, change their place of employment, and earn money. Wandering around different countries was also mentioned:

"I have been twice on this farm. I have also been in Poland, England, and Ireland, where we picked apples. In Denmark and in Russia, I was working on a pig farm. An opportunity to earn money made me come to Finland to pick berries" (male, 27 years old, graduated from agricultural university in Ukraine, also had farm work experience at home).

\section{Work}

A supportive work environment, being well-informed about the day's work, receiving positive feedback, and feeling that the employer listens to employees' opinions and treats all employees fairly and amicably were important factors when considering job satisfaction. The workers appreciated basic things, such as a ready lunch in high season times, warm water, warm accommodation, and an employer who can speak at least some words of their language because that makes communication easier. Receiving no feedback or response to their ideas and suggestions, and unclear organization of the work were considered negative factors:

"Concerning work practices, I wish that we would get to know next day's work tasks. I have had plenty of conflict situations because everybody wants to be a boss" (male, 20 
years old, first time on the present farm, earlier experience in farm work at home).

"The work really is hard and physical. We get help from workmates, particularly in the beginning. In the beginning it was hard times because we didn't know the language. The employer was studying Russian, but she was able to speak only a little. Now she speaks good Russian. There are always some side issues that we don't like, such as if there is not enough water when there are a lot of workers on the farm" (female, 50 years old, education and experience in agriculture, over ten years of seasonal work on the present farm).

"The employer said thank you for a good job. And a client said the berries are high quality. I haven't got any other feedback, but I would like to. I have a feeling that the employer treats us equally. She divides the work without hurting anybody" (female, 23 years old, agricultural education).

The physical burden of the work emerged clearly in the workers' comments when discussing work conditions and straining factors. Inconvenient working positions, repetitive work, and heavy loads make agricultural and horticultural tasks physically straining. In addition, weather conditions and long working hours further increase the exposures:

"At the beginning, I found this work horrible. It was really hot. After ten minutes, I thought I cannot work here, but then I got used to it" (female, 36 years old, six years working in the present greenhouse, previous farm work experience at home).

"I recommend others to come pick berries in Finland. They can earn money, there are a lot of farms, and work conditions are normal. The work, picking strawberries, is easier for girls than for men. For newcomers who want to come to Finland and pick berries, I would advise them to be fit and good at sports. The work is hard, especially for the feet and back" (male, 26 years old, six seasons on the present farm, also worked on a horticultural farm in Denmark).

"In this work, the heaviest thing is the picking of strawberries. The best things that help me to manage are the warm lunch and the good work team. The most important thing is to remember that it is seasonal work and you have to work quickly, then you can earn a good salary. In this work, you have to be persistent and exact" (female, 23 years old, first season, earlier experience and education in farm work).

Especially in open-field horticultural production, ripening of the yield and the market situation have impacts on the intensity of the work, and changes in the work situation may occur on short notice. Workers described short working hours or a total lack of work, which cut their earnings, and that it was difficult to find alternative work tasks. On one farm, a group of people departed abruptly because there was no work when they arrived. Some workers might also have had unrealistic expectations about earnings, or they might have received inadequate or incorrect information. The work is hard, the season is short, and it can be difficult to reach the desired earning level:

"Last year, I earned only travel expenses" (female, 20 years old, student, earlier experience in farm work).

The extent of orientation varied among the farms. On one farm, the employer took only five minutes to explain the operation and provided the workers with a tractor manual to read. On another farm, orientation was more of an everyday process of teaching and learning. The language barrier limited the extent and form of orientation. Showing workers how to perform tasks and providing feedback were typical, but written instructions, videos, and internet-based instructions were rare. The use of videos in mentoring and initial orientation was mentioned on only one of the four farms in the second part of the study. The content of the teaching was mostly "how to do the job", such as which lettuces were ready for 
harvesting or how to harvest strawberries, but simple safety instructions were also provided, e.g., the importance of drinking enough water, using protective clothing to prevent sunburn, how to handle knives while harvesting, and the local emergency phone number. Usually, some workers provided or translated information for others, or they all used Russian (or Ukrainian in 2018-2019) to communicate. Especially in the later interviews, the need to understand the instructions and an interest in education and advancement came up among long-term workers:

"It would be great if the farm expanded and I got more responsibilities. I love tractor work and being a foreman, and I hope to get my family here to stay" (male, 39 years old, five years of experience on the present farm).

"If I stay at work here, I want to get a promotion" (male, 28 years old, 4.5 years of experience on the present farm).

Initial orientation of new workers, which was often the duty of experienced workers, was also mentioned as a straining factor. The worker community on a farm can be quite unstable. Workers and trainers come and go; some might come back every year, while others stay for only one season. Changing co-workers and supervision of peer workers were found straining, especially when language and cultural barriers exist:

"I wish there were fewer new workers, because I have to supervise them. I wish also that the work team would be permanent" (female, 27 years old, six years of experience on the present farm, and other farm work experience).

"It is hard to find a common language and try to teach others" (male, 28 years old, language skills in English, Russian, Ukraine, and Finnish, four years of experience on the present farm, and other farm work experience).

Work tasks were perceived as demanding, especially in animal production:

"This work has been more difficult than I assumed. For my first time, my wife was also here, luckily enough, and she advised me. The farmer's wife gave me advice concerning the work processes in the cowshed. The farmer told me how to use the machinery" (male, 29 years old, second time on the present farm, no other experience with farm work).

\section{Health and Injuries}

In this study, we focused on experiences regarding action in case of injury or illness. The workers said that they would ask for help from their employer, foremen, or co-workers if something happened, and they were also ready to help other workers. However, all of them were not ready to call the emergency number, even if they knew it, because of language difficulties and lack of information on how to act. Workers had received medical help when needed, but there was some confusion about disability time compensation and about their right to medical services. Some workers avoided going to the doctor because of language problems or earlier experiences. People from nearby areas preferred to return home temporarily if they became ill. The workers also tried to handle the situation with self-care:

"I would call the emergency number, 112. I know when it is okay to call. I can tell the address" (female, 33 years old, first time on the present farm).

"I had an accident and I suffered burns to my face. Workmates brought me to the farm, and the employer took me immediately to the hospital. I was three days at home and got sick leave compensation" (male, 52 years old, over ten years seasonally on the present farm).

"Last year, I was four days absent from work. I had fever. I didn't get any sick leave 
compensation" (female, 19 years old, three years on the present farm).

"Last week, I had pain in my side. I visited a doctor in a hospital in Vyborg [Russia]. Here, visiting a local health center is difficult, because even if my employer knows some Russian, those kinds of words she doesn't know. If I would meet a doctor here, I wouldn't understand anything. Vyborg is a short distance, and I have a car" (female, 41 years old, over ten years seasonally on the present farm).

\section{Family and Close Community}

Working abroad usually means separation from home and family, and many workers suffered from homesickness:

"I want to go home" (female, 27 years old, six years on the present farm, wants to stay, works and studies in Finland but misses home).

"I miss my home, my daughter" (female, 28 years old, second season on the present strawberry farm, intends to stay one month).

However, new technology, such as smart phones and tablets, has become popular (as noted in the later interviews), which simplified communication with families. Workers who stay in Finland for long periods have tried to combine family life with working abroad in different ways, e.g., by taking their family with them or by trying to accommodate their working periods to the situation at home and to the needs of their children. Bringing a family to Finland is expensive, and it can be impossible for migrants from non-EU countries. Migrant workers have to prove to the authorities that they can support their family in Finland, which is difficult because wages are not high in the agricultural sector. Working a short distance from home helps; it is easier to visit home, or the family can come to visit Finland. On the other hand, foreign workers in Finland sometimes had social pressures from home. Many of their acquaintances would like to work in Finland, and they ask or even pressure the foreign workers to find a job for them:

"Usually, they ask me to find a job. I already found a job for one of my friends. She came, worked, and got married. They do not understand that there are no big cities and not a lot of jobs here. There are only a few jobs, and I cannot help, but they do not understand it. If there is a job, I will tell them about it" (female, 36 years old, six years on the present farm).

Social life and communication with local people are limited because of language problems. In addition, finding needed information (e.g., health services, what to do if a child falls ill, or where to get information about pension records) can be difficult. Limited and superficial social relations can be frustrating:

"The most inconvenient thing is that I do not understand the language. I cannot chat with people. I do not know how to explain things" (female, 51 years old, six years of farm work in Finland, and farm work experience at home).

Working on a farm usually means living deep in the countryside. It can also mean living with dozens of strangers and sharing facilities, such as the kitchen, sauna, showers, and toilets, which can be stressful. In addition to the difficulties of living together, other conflicts between workers were mentioned, such as stealing of baskets (for berry picking), disagreement about work tasks, and an unpleasant work atmosphere.

Conflicts between workers and their employers consisted of misunderstandings due to the language barrier, as well as disagreements about wages, taxes, and weekend or overtime work compensation. Working as a team leader and messenger between the employer and the employees can also be awkward: 
"I have had disagreements here with my employer about the salary and taxes. The employer does not follow the rules. He does not pay overtime and Sunday compensation. On the farm, I'm also doing other than farm work. Some workers do not do their jobs, and I'm a team leader. My boss does not understand that I am just translating the comments of other workers. There have been misunderstandings, because I don't always understand things right, because of my Finnish language skills" (male, 26 years old, six seasons on the present farm).

\section{Discussion}

The interview data revealed several motivational, supporting, and straining factors that can be used in improving the working life of foreign farm workers.

Economic reasons and a low standard of living at home are typical reasons for migration and were mentioned in our interviews. Hettige et al. (2012) indicated that pushing reasons can also include other challenges, such as a spouse's alcohol addiction or violent behavior. Pulling factors in our data included the strong role of personal networks and earlier experiences, as well as a desire for adventure. The second part of our study revealed some new aspects, such as the use of recruitment services, but personal networks still had a strong role in the recruiting and information process. Rogaly (2006) suggested that there may be a change toward intensification of workplace operations, as workers seeking to maximize their earnings are willing to work long hours for short periods of time on short notice. This type of recruitment favors migrant workers whose main motivation is to earn as much as possible in a short time. From the viewpoint of occupational health and safety, this type of employment can be dangerous. Piece rate pay, which is commonly used in seasonal work, also has well-recognized negative effects on health and safety (Johansson et al., 2010).

Work in the horticultural sector is physically hard, which came up in the worker comments. High incidence of musculoskeletal disorders in labor-intensive practices like harvesting fresh fruits and vegetables is well known (e.g., Kirkhorn et al., 2010; Fathallah, 2010). Risk factors vary between production sectors, but typical risk factors for musculoskeletal disorders in agriculture include prolonged and repetitive stooping, repetitive cutting, lifting, and carrying of heavy loads, climbing ladders with heavy loads, extreme climate, vibration, and noise (Fathallah, 2010). In horticulture, some improvements have been established, such as the use of stools and prone carts, but the need for further development is obvious. Moreover, our findings suggest that psychosocial and personal characteristics should be also considered when aiming to reduce musculoskeletal symptoms.

There has been criticism that the use of low-paid and willing foreign workers creates a situation in which no improvements in working conditions are needed to attract more labor to the sector (Brox, 2006), even though inequitable working conditions affect the wellbeing of farmworkers in general, including physical injuries and mental health issues (Holmes, 2019). However, our results do not fully support that argument. While Finnish employers have a legal responsibility to take care of their workers and improve their working conditions, better working conditions may also reduce worker turnover and thus reduce recruiting costs, improving the overall resilience of the farm. Workers are more eager to come back if the working conditions and wages are satisfactory to them. Because many of the workers find work through personal networks, it is important to have a good reputation as an employer. With better ergonomics and co-operation in occupational safety and health issues among the employers, the workers, and occupational health personnel, agricultural 
work could improve its attractiveness for both foreign and domestic labor. This could decrease the costs of work-related disabilities and improve farm productivity.

A motivated and flexible workforce is needed for hard work during short periods (e.g., picking strawberries) as well as for other tasks for which education is not necessarily required. However, when the work is more complicated, such as in modern animal production or when working with machinery, more skills are also needed. Leppälä et al. (2012) found that larger and more complex farms need more management skills, and the skills needed may differ by farm production type. Based on our findings, foreign workers perform demanding tasks, including work as supervisors, handling exceptional situations, and taking care of animals. However, the workers' language skills and qualifications are not necessarily at the required level. Orientation, training, and vocational education for foreign workers and foremen should be developed in the future. This could be done in cooperation with other Nordic countries that have similar on-farm working conditions.

Ahonen et al. (2009) noted that long working hours and limited economic resources prevented foreign workers from pursuing language studies that could help them get a better job or a job matching their education. Progress in language skills could also enable progress in work skills (e.g., understanding animal welfare, operating automated equipment) and would probably make farm work more attractive. A diversity of work tasks has been found to improve the self-reported happiness of foreign farm workers (Cross et al., 2008). A satisfactory work environment is at least as important for workers' health as their socioeconomic status (Gupta and Kristensen, 2008).

A lot can be done with good leadership and communication (Menger-Ogle et al., 2019). The information needs of workers vary, and the information should be customized to meet specific needs. The user-centered design approach is recommended for developing safety training materials for foreign farm workers (Vigoroso et al., 2020).

Based on the worker's stories concerning injury or illness, there is lack of information on medical services and the workers' rights to compensation. Long-term workers need information on other services as well, such as healthcare for their children (Rye, 2018). Better information could reduce misunderstandings and conflicts. The workers tended to avoid using local services, which is important for researchers to consider when using registered injuries or illnesses in epidemiological studies and when planning the control of infectious diseases. Under-reporting of work-related injuries to supervisors has been noted in earlier studies (Liebman et al., 2016; Menger-Ogle et al., 2019). Weaknesses in communication and cooperation limit the supervisor's ability to identify work hazards and improve working conditions (Rautiainen et al., 2012).

Being a foreign worker places an individual in a special social situation. Being separated from and missing family and friends is probably the most obvious challenge. Shorter geographic and cultural separation makes life easier in the new country or region (Labrianidis and Sykas, 2009). As noted in the second part of our study, communication technology has improved, and the workers and their families were able to interact online, as discussed by Rye (2018). In the U.S., Latino migrant workers have been widely studied; however, as Rodrigues (2013) stated, only few studies have focused on social support and the possibilities of using modern technology to reduce psychosocial stressors.

Based on our findings, foreign farm workers face many challenges at home and in their destination country, such as social pressures from family and friends, isolation, living with strangers, and lack of privacy. The psychosocial aspects of being a foreign farm worker in the Nordic countries have not been widely studied, nor have their impacts on the well-being 
and occupational safety of workers. In Norway, Riber (2009) mentioned the uncertainty of life ahead, rootlessness after a long period of migration, and the importance of meaningful relationships and as well as relations with the surrounding society, which also emerged in our findings. However, difficult situations at home or in other aspects of life might have an even stronger impact on distress than the factors related to migration (Leavey et al., 2007) or working conditions in the host country. On the other hand, working abroad also affects a person's social attitudes and behavior (Akopova and Ruza, 2010).

As noted by Rye (2018), many foreign workers have changed from recent to established newcomers, which has altered their expectations. They might have planned to work only for one season but stayed permanently after finding another place of employment (Spencer et al., 2007) or stayed with the original employer (McAreavey, 2012). In Greece, Kasimis et al. (2010) pointed out that foreign workers often shift from one employment sector to another, according to the needs of the local labor market. A recent study in Scotland showed that migrants' decisions to stay longer in rural areas are linked to both the material and emotional aspects of their social security (Flynn and Kay, 2017).

\section{Strengths and Limitations of Study}

The strengths of this study include a relatively large sample size representing a diverse foreign worker population by age, gender, nationality, education, farm type, work experience, and mode of recruitment. The interviewers were able to communicate with the workers effectively and obtain a great number of straining and supporting factors affecting the workers' living and working conditions on Finnish farms. The questions and findings were organized systematically in themes, and the responses were recorded and analyzed with attention to factors that can be considered by employers for improving the working and living conditions of foreign workers.

The limitations of this study include the lack of statistical information about seasonal foreign farm workers. With limited information on the numbers and characteristics of foreign farm workers in Finland, it was not possible to provide a reliable assessment of the representativeness of our sample during the years of the study. However, we attempted to carefully select farms to obtain diverse representation by sex, experience, employment type, and production sector.

Self-selection could have affected our results. The farms and employers interested in participating may have had greater interest in the well-being of their employees. Farms that have more problems with their working conditions and job satisfaction would be less likely to participate. This can create a bias, and the results may not be fully representative of all farms that hire foreign workers in Finland. However, the aim of this study was to find areas for development, rather than to measure and document potential problems. In general, development activists (change agents) typically improve their operations first, and others follow when they see the results.

Finally, when conducting the face-to-face, on-farm interviews with vulnerable workers, it is possible that the interviewees were cautious in their comments. However, particularly in the first part of the study, the workers talked openly about difficult issues and feelings. In the second part of study, their comments focused more on how to improve their working conditions and practices.

\section{Conclusions}

During the past 20 years, migrant and immigrant labor has become a permanent part of 
Finnish agriculture. Although the number of foreign workers is still relatively small, their contribution to the Finnish agricultural sector is strong, which has become apparent during the Covid-19 pandemic. In particular, the horticultural sector is highly dependent on seasonal foreign workers. This study focused on the working and living conditions of foreign workers. The findings are similar to findings in other parts of Europe; however, in contrast to other EU countries, the majority of foreign workers in Finland come from non-EU countries, particularly Russia and Ukraine. The EU citizens working in Finnish agriculture are mainly Baltic, which emphasizes the role of geographic distance in the recruitment process. Therefore, the cultural differences between the employers and employees are relatively small, at least when comparing Finland to countries in southern Europe.

Based on our findings, employers could contribute to better working and living conditions for foreign workers by reducing physical strain and improving training and communication in the workplace. The supporting and straining factors emphasize the role of supervisors in planning, informing, motivating, rewarding, promoting, teaming up, and supporting the physical and mental well-being of their workers. Enhancing the competence of supervisors could develop the well-being of foreign farm workers. Further education for foremen and foreign workers should be developed in the future.

\section{Acknowledgements}

We want to thank all workplaces that participated in this study. The study was funded by the Finnish Work Environment Fund, MTT Agrifood Research Finland, TTS Work Efficiency Institute, Finnish Institute of Occupational Health, and Central Union of Agricultural Producers and Forest Owners (MTK). Additional data were collected in a project funded by the European Social Fund (ESF), Farmers' Social Insurance Institution (Mela), Natural Resources Institute Finland (Luke), TTS Work Efficiency Institute, and Potato Research Institute. Professor Risto Rautiainen's efforts in this study were partially supported by CDC/NIOSH Award No. U54OH010162 to the Central States Center for Agricultural Safety and Health at the University of Nebraska Medical Center.

\section{References}

Ahonen, E. Q., Porthé, M. L., Vázquez, M. L., García, A. M., López-Jacob, M. J., Ruiz-Frutos, C., ... Benavides, F. G. (2009). A qualitative study about immigrant workers' perceptions of their working conditions in Spain. J. Epidemiol. Commun. Health, 63(11), 936-942. https://doi.org/10.1136/jech.2008.077016

Akapova, I., \& Ruza, A. (2010). The impact of EU post-enlargement labour migration on social attitudes of migrant workers: An example of Latvia. Intl. J. Interdisc. Soc. Sci., 5(2), 485-498. https://doi.org/10.18848/1833-1882/CGP/v05i02/51592

Alexe, D. M., Petridou, E., Dessypris, N., Skenderis, N., \& Trichopoulos, D. (2003). Characteristics of farm injuries in Greece. J. Agric. Saf. Health, 9(3), 233-240. https://doi.org/10.13031/2013.13688

Beyer, H., \& Holtzblatt, K. (1998). Contextual design. San Francisco, CA: Morgan Kaufmann.

Braun, V., \& Clarke, V. (2006). Using thematic analysis in psychology. Qual. Res. Psych., 3(2), $77-$ 101. https://doi.org/10.1191/1478088706qp063oa

Brox, O. (2006). The political economy of rural development. Modernisation without centralisation? Utrecht, Netherlands: Eburon Academic Publishers.

Cross, P., Edwards, R. T., Hounsome, B., \& Edwards-Jones, G. (2008). Comparative assessment of migrant farm worker health in conventional and organic horticultural systems in the United Kingdom. Sci. Total Environ., 391(1), 55-65. https://doi.org/10.1016/j.scitotenv.2007.10.048

Dwyer, J., Micha, E., Kubinakova, K., van Bunnen, P., Schuh, B., Maucorps, A., \& Mantino, F. 
(2019). Evaluation of the impact of the CAP on generational renewal, local development, and jobs in rural areas. Final reports. Luxembourg: European Comission, Directorate-General for Agriculture and Rural Development.

Fathallah, F. A. (2010). Musculoskeletal disorders in labor-intensive agriculture. Appl. Ergon., 41(6), 738-743. https://doi.org/10.1016/j.apergo.2010.03.003

Finlex. (2014). Finlex data bank. Helsinki, Finland: Ministry of Justice. Retrieved from www.finlex.fi

Flynn, M., \& Kay, R. (2017). Migrants' experiences of material and emotional security in rural Scotland: Implications for longer-term settlement. J. Rural Studies, 52, 56-65. https://doi.org/10.1016/j.jrurstud.2017.03.010

Gould, R., Ilmarinen, J., Järvisalo, J., \& Koskinen, S. (Eds.). (2008). Dimensions of work ability: Results of the Health 2000 Survey. Helsinki, Finland: Finnish Centre for Pensions, Social Insurance Institution, National Public Health Institute, Finnish Institute of Occupational Health. Retrieved from https://sivusto.kykyviisari.fi/wp-content/uploads/2018/09/Gould-Dimensions-ofwork-ability.pdf

Gupta, N. D., \& Kristensen, N. (2008). Work environment satisfaction and employee health: Panel evidence from Denmark, France, and Spain, 1994-2001. European J. Health Econ., 51-61. https://doi.org/10.1007/s10198-007-0037-6

Hettige, S. T., Ekanayake, E. S., Jayasundere, R., Rathnayake, A., \& Figurado, P. (2012). Understanding psychosocial issues faced by migrant workers and their families. Bern, Switzerland: Federal Department of Foreign Affairs (EDA). Retrieved from https://www.eda.admin.ch/dam/ countries/countries-content/sri-lanka/en/emb_colombo_resource_en_224603.pdf

Hoggart, K., \& Mendoza, C. (2000). African immigrant workers in Spanish agriculture. San Diego, CA: University of California, Center for Comparative Immigration Studies. Retrieved from https://ccis.ucsd.edu/_files/wp2.pdf

Holmes, S. M. (2020). Migrant farmworker injury: Temporality, statistical representation, eventfulness. Agric. Human Values, 37(1), 237-247. https://doi.org/10.1007/s10460-019-09965-8

Ilmarinen, J. (2006). Towards a longer worklife! Ageing and quality of worklife in the European Union. Helsinki, Finland: Finnish Intitute of Occupational Health, Ministry of Social Affairs and Health.

Johansson, B., Rask, K., \& Stenberg, M. (2010). Piece rates and their effects on health and safety: A literature study. Appl. Ergon., 41, 607-614. https://doi.org/10.1016/j.apergo.2009.12.020

Kasimis, C., Papadopoulos, A. G., \& Pappas, C. (2010). Gaining from rural migrants: Migrant employment strategies and socioeconomic implications for rural labour markets. Sociologia Ruralis, 50(3), 258-276. https://doi.org/10.1111/j.1467-9523.2010.00515.x

Kirkhorn, S., Earle-Richardson, G., \& Banks, R. J. (2010). Ergonomic risks and musculoskeletal disorders in production agriculture: Recommendations for effective research to practice. $J$. Agromed., 15, 281-299. https://doi.org/10.1080/1059924X.2010.488618

Labrianidis, L., \& Sykas, T. (2009). Geographical proximity and immigrant labour in agriculture: Albanian immigrants in the Greek countryside. Sociologia Ruralis, 49(4), 394-414. https://doi.org/10.1111/j.1467-9523.2009.00494.x

Leavey, G., Rozmovits, L., Ryan, L., \& King, M. (2007). Explanations of depression among Irish migrants in Britain. Soc. Sci. Med., 65, 231-244. https://doi.org/10.1016/j.socscimed.2007.03.022

Leppälä, J., Murtonen, M., \& Kauranen, I. (2012). Farm risk map: A contextual tool for risk identification and sustainable management on farms. Risk Mgmt., 14(1), 42-59. https://doi.org/10.1057/rm.2011.14

Liebman, A. K., Juarez-Carrillo, P. M., Reyes, I. A., \& Keifer, M. C. (2016). Immigrant dairy workers' perceptions of health and safety on the farm in America's heartland. American J. Ind. Med., 59(3), 227-235. https://doi.org/10.1002/ajim.22538

Luke. (2019). Statistics database. Helsinki, Finland: Natural Resources Institute Finland. Retrieved from http://statdb.luke.fi/PXWeb/pxweb/en/LUKE/?rxid=786f0450-355f-4a91-af51-6898606f4e0f

McAreavey, R. (2012). Resistance or resilience? Tracking the pathway of recent arrivals to a 'new' rural destination. Sociologia Ruralis, 52(4), 488-507. https://doi.org/10.1111/j.1467- 
9523.2012.00573.x

McNamara, J., Leppälä, J., Laan, G., Colosio, C., Jacob, M., Van den Broucke, S., ... Rautiainen, R. (2018). Safety culture and risk management in agriculture (Sacurima). Abstract for the 32nd Triennial Congress of the International Commission on Occupational Health (ICOH). Occup. Environ. Med., 75(supp. 2), A462. https://doi.org/10.1136/oemed-2018-ICOHabstracts.1314

Menger-Ogle, L. M., Pezzutti, F., Menger-Ogle, A. D., Stallones, L., Rosecrance, J., \& RomanMuniz, I. V. (2019). Occupationl safety and health of foreign-born, Latinx dairy workers in Colorado. J. Occup. Environ. Med., 61(1), 61-68. https://doi.org/10.1097/JOM.0000000000001472

Mikkola, N., \& Morales, A. H. (2017). Finland: Pirkanmaa region and Punkalaidun municipality. In L. G. Harbo, T. Heleniak, \& A. S. Hildestrand (Eds.), From migrants to workers. Regional and local practices on integration of labour migrants and refugees in rural areas in the Nordic countries (pp. 48-55). Nordregio Working Paper 2017:5. Retrieved from https://www.divaportal.org/smash/get/diva2:1129282/fulltext01.pdf

Ovaska, U., Leppälä, J., Mattila, T. E., \& Sinisalo, A. (2011). Ulkomainen kausityövoima maatiloilla. Maaseudun Uusi Aika, 2, 55-59. Retrieved from http://www.mua-lehti.fi/wpcontent/uploads/2018/02/MUA_2011_2_pu_Ovaska.pdf

Peri, G. (2016). Immigrants, productivity, and labor markets. J. Econ. Perspect., 30(4), 3-30. https://doi.org/10.1257/jep.30.4.3

Ramos, A., Girdžiūtè, L., Starič, J., \& Rautiainen, R. H. (2020). Identifying “vulnerable agricultural populations" at risk for occupational injuries and illnesses: A European perspective. J. Agromed., 27, 1-6. https://doi.org/10.1080/1059924X.2020.1771498

Rautiainen, R. H., Heiberg, A.-M., Mattila, T. E., Kaustell, K., \& Danielson, A. (2012). Factors affecting occupational safety and health of foreign farm workers in Nordic countries. TemaNord 2012:530. Copenhagen, Denmark: Nordic Council of Ministers. https://doi.org/10.6027/TN2012530

Riber, S. (2009). Bare en gjestearbeider? En kvalitativ studie om hvordan kvinnelige arbeidsinnvaradrere I veksthusnaringen forhandlar om livet som arbeidsinnvandrer og tilvarelser “in between". Bugdeforkning Rapport 12/09. Trondheim, Norway: Centre for Rural Research.

Rodrigues, R. (2013). Exploring social support in migrant and seasonal farmworkers in south Georgia. MA thesis. Atlanta: GA: Georgia State University. Retrieved from $\mathrm{http} / / /$ scholarworks.gsu.edu/psych theses/102/

Rogaly, B. (2006). Intensification of work-place regimes in British agriculture. The role of migrant workers. Sussex Migration Working Paper No. 36. Brighton: UK: University of Sussex, Sussex Centre for Migration Research.

Rye, J. F. (2018). Labour migrants and rural change: The "mobility transformation" of Hitra/Froya, Norway, 2005-2015. J. Rural Studies, 64, 189-199. https://doi.org/10.1016/j.jrurstud.2017.12.003

Rye, J. F., \& Andrzejewska, J. (2010). The sturctural disempowerment of eastern migrant farm workers in Norwegian agriculture. J. Rural Studies, 26(1), 41-51. https://doi.org/10.1016/j.jrurstud.2009.06.003

Schuh, B. (2019). Research for AGRI Committee - The EU farming employment: Current challenges and future prospects. Brussels, Belgium: European Parliament, Policy Department for Structural and Cohesion Policies.

Spencer, S., Ruhs, M., Anderson, B., \& Rogaly, B. (2007). Migrants' lives beyond the workplace. The experiences of central and east Europeans in the U.K. York, UK: Joseph Rowntree Foundation.

Vigoroso, L., Caffaro, F., \& Cavallo, E. (2020). Occupational safety and visual communication: Usercentred design of safety training material for migrant farmworkers in Italy. Saf. Sci., 121, 562-572. https://doi.org/10.1016/j.ssci.2018.10.029 